\title{
ENERGY OPERATION NETWORK PROMOTION FOR MODELS OF INFORMAL EDUCATION
}

\author{
How-Gao Hsu ${ }^{1}$, Hsiu-Ching Shih ${ }^{2, *}$ \\ ${ }^{1}$ Department of Industrial Education, National Taiwan Normal University, Taipei, TAIWAN \\ ${ }^{* 2}$ Department of Applied English, De Lin Institute of Technology, Taipei, TAIWAN \\ *Correspondence Author: daphne568@gmail.com
}

\begin{abstract}
This study aims to compile teaching materials designed for students to gain hands-on experience in energy conservation and carbon reduction, also to create maneuverable teaching tools to simulate renewable energy operation. In order to achieve the set teaching goals, meetings of experts were summoned to verify and revise related literature as groundwork for the development of teaching tools. To complete our teaching materials, we digitized and posted them on education network under energy conservation and carbon reduction so students can learn and assemble teaching tools online as well. As a result of the integration of classroom instruction and the education computer network in information sharing among the students have become prevalent. The results revealed the following: 1. the hands-on experience obtained on energy topics at the teacher's training camp helps to raise the energy consciousness of the college students. 2. the attitude, subjective norm and conscious behavior control of the college students will affect their behavioral intention on energy conservation and carbon reduction. 3. Hands-on experience with maneuverable teaching tools helps the elementary school students with their energy perception. 4. Learning from experience rather than knowledge from academic instruction tends to attract more learning interest from the students.
\end{abstract}

Keywords:

Energy conservation, hands-on experience, informal education, teaching

\section{INTRODUCTION}

In 2005 the UNDESD (United Nations Decade of Education for Sustainable Development) was proclaimed by UNESCO, listing global warming as one of the core subjects of education [1]. Following the Kyoto Protocol, in order to curtail the greenhouse effect caused by climate change, the 2009 United Nations Climate Change Conference was held in Copenhagen, the capital of Denmark. The conference included the 15th Conference of the Parties (COP 15) to the United Nations Framework Convention on Climate Change (UNFCCC) to set the goals and practices for climate change mitigation until 2020 [2]. In April 2009 the Taiwan Government held a national conference on energy in an effort to reach a national consensus on energy conservation and carbon reduction. One of the conclusions was that in order to make popular science more accessible to the general public, also to raise the public awareness on energy conservation and carbon reduction, seed teachers and volunteers from both the public and private sectors need to 


\section{INTERNATIONAL JOURNAL of RESEARCH -GRANTHAALAYAH

be properly trained first. Also, digital learning curriculums need to be developed, and data bank established and managed. As was stated above, it could be concluded that energy education in Taiwan should not be limited to campus only anymore; rather, an informal unconventional system seems indispensable to the energy education on the island.

The purposes of this study is to develop teaching materials/curriculums of energy conservation and carbon reduction, also teaching media and teaching tools/experimental modules involving renewable energy. The research results will then be turned into digitized materials to establish a comprehensive website for the education of energy saving and carbon reducing. With the teaching materials available in either real or virtual type, the learners can learn through this website the basic concept of energy and the technological aspects of the renewable energy. Specifically, the purposes of this study are as follows:

- To research and develop maneuverable teaching tools/experimental modules for renewable energy.

- To establish an educational website for energy conservation and carbon reduction (http:phsu.ie.ntnu.edu.tw/ienergy/).

- to hold activities for participants to gain knowledge of energy and hands-on experience

(1) To found a "Future energy teacher's experiential training camp" to train college students to become seed teachers.

(2) To found a "Student experiential learning camp" for elementary/junior high school students to raise their awareness of energy issues and to arouse their curiosity and interest in energy science by letting them do the experiments on their own.

It is a known fact that global warming is caused by the large consumption of the fossil fuels. According to the report of IPCC (Intergovernmental Panel on Climate Change) of United Nations, since 1990 the earth's surface temperature has been increasing about 0.2 degree Celsius every decade and a global warming of 3-5 degrees Celsius is projected by 2100 [3].

In view of the importance of energy education and renewable energy exploration, the Government has listed equipped facilities and teaching tools for teaching/demonstration as vital items in the promotion of energy education. It is also revealed that most teachers feel that the goals of promoting energy education can hardly be achieved through academic instruction and the abstract concept of energy alone is not helpful enough in the energy education development. Wu. Wang and Huang [4] pointed out that the difficulties encountered were, in order of their seriousness, absence of cognition, lack of proper curriculum and insufficient resource/facility. Similar view that they attributed the ineffective learning to the lack of efficient instruction and package curriculum plan [5]. In the past, the school teachers tended to stress the transfer of knowledge which was often supplemented with extracurricular reading and other materials. However, a systematic approach of learning from experience was rarely seen. Moreover, most available teaching tools today for renewable energy education are nothing more than some 


\section{INTERNATIONAL JOURNAL of RESEARCH -GRANTHAALAYAH

artifacts. While it is possible to do experiments with them, yet they can only provide little or no pragmatic experience for the learners. This is evidenced by the ineffective learning, poor attitude and lack of initiative on the learner's part. With the above drawbacks in mind, this study has constructed curriculums emphasizing the acquisition of hands-on experience to integrate theory and practice into course design in the hope of bringing the abstract concept of renewable energy/energy saving to life. With the above help, students will be inspired; their curiosity and observation activated, which will inevitably lead them to their voluntary exploration of the related issues. Their correct cognition obtained from the process will undoubtedly lay a firm foundation to their energy education.

Energy is the main driving force of economic development and prosperity. As civilization advances, a variety of non-renewable energy sources such as crude oil, natural gas and coal has been consumed. The massive use of these resources will generally result in not only the exhaustion of such resources but also the inevitable emission of compounds to hurt our environment. Therefore, the sound energy policy of our country needs to focus on plans to increase energy efficiency, to promote renewable energy with environmental protection in mind and to enhance energy saving education. Renewable energy is a clean resource which is naturally replenished. Good examples would be sunlight, wind, water, tides, biofuels and geothermal energy. In addition, the Taiwan Energy Bureau of Ministry of Economic Affairs has also set goals of developing renewable energy, aiming at the development of these non-carbon emitting energy sources to effectively develop their potentials in 2008. Considering the existing conditions and the future objectives, the Bureau has singled out hydroelectricity, windmill electricity, solar electricity and biofuels as the target items in hopes that Taiwan will prevail in the renewable energy technology industry in this trend of global warming mitigation and carbon reduction.

The educational website for energy conservation and carbon reduction website is created to enhance students' knowledge and to foster future talents in the area of energy research and development. By way of the transfer of knowledge (existing and new), skills and correct methods, this website's final goal is to increase the effectiveness of energy as a whole. With its built-in interactive platform, this website can also allow elementary/junior high school students to study energy at their own convenience. 


\section{INTERNATIONAL JOURNAL Of RESEARCH -GRANTHAALAYAH

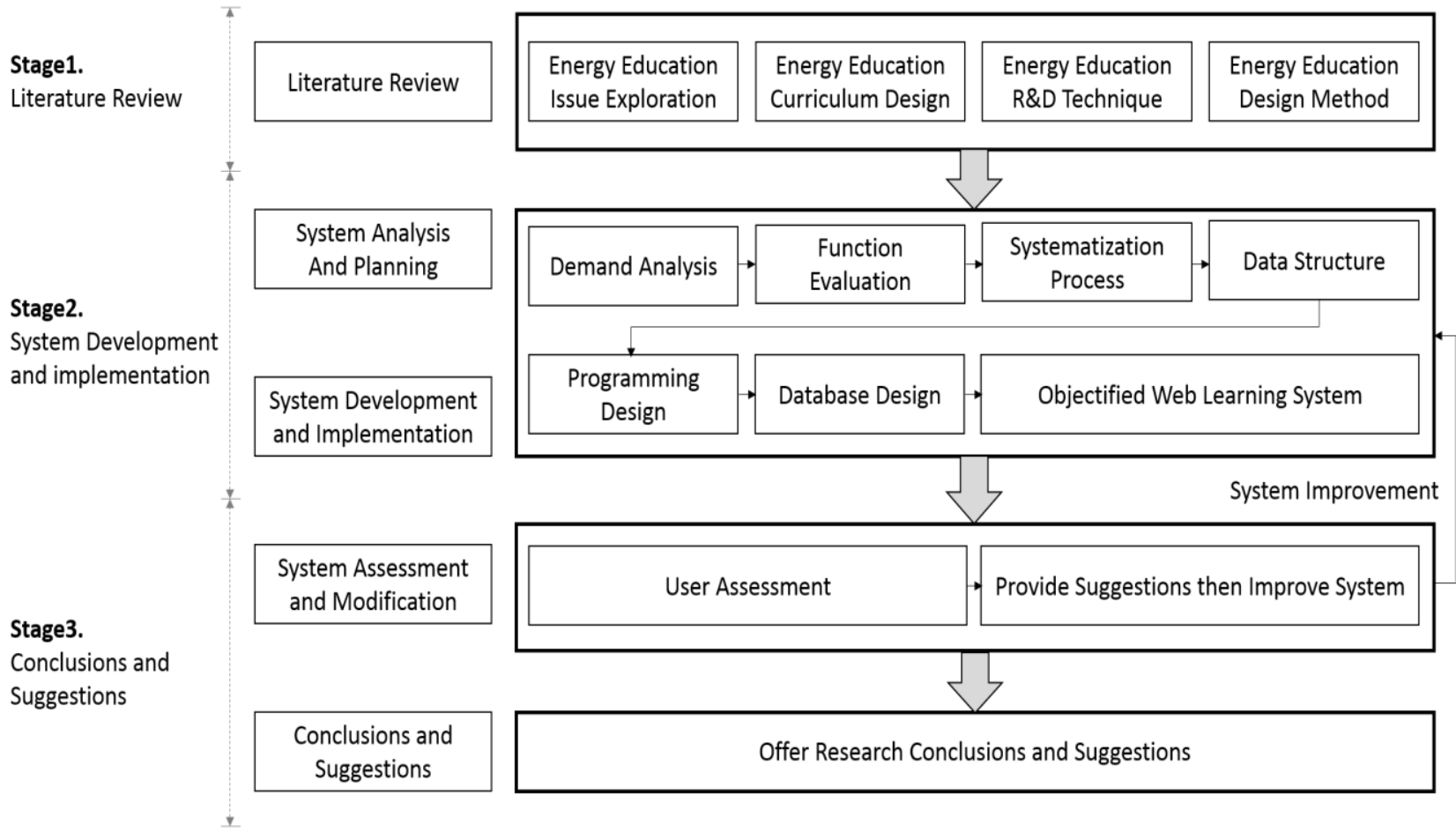

Stage3.

Conclusions and

Suggestions

Figure 1: Stages of designing energy education interactive platform

The modern society is changing so rapidly that the student-centered curriculums and learning activities sometimes just can not offer classroom courses/activities to keep up with the ever changing social issues. Lately, the informal science education has become an indispensable segment to the science education reform. In particular, in an informal setting of science education, the vivid demonstration, activities and the pluralism in learning will undoubtedly inspire the learners in many ways. Tyler regarded the effective curriculum planning to be a continuous, cyclical process; an instrument of education that needs to be fine-tuned [6]. Dewey pointed out that learning should be a process of the reorganization of experience and the accumulation of knowledge [7]. The experience and knowledge can be connected together for use in the school and the outside world. Therefore, the purpose of adjusting a curriculum is trying to consolidate the learning pieces of students into a meaningful, appropriate and effective learning process for them. Oliver proposed that the gap between curriculum and student's need was caused by 1.interdepartmental conflict; 2.theory and practice not linked together; 3.school and modern living not connected and school not utilizing community resources [8]. In view of the above comments and assertions from other science educators, it is suggested that the informal settings of education can provide people of all ages with ample social resources to study science. Fenichel \& Schweingruber suggested that the informal educational institutions could provide a 


\section{INTERNATIONAL JOURNAL of RESEARCH -GRANTHAALAYAH

social environment in which the learners could also learn from others' experiences and strategies [9]. In addition, the settings also provide a platform for digital learning so teachers are able to combine online resources with school teaching to help students achieve their learning goals whereas the formal science classroom teachers can't.

From the viewpoint of learning, Vygotsky perspective stressed on social interaction by saying that the human learning takes place through the interaction with their environment [10]. Pragmatists contended that knowledge is like a tool and is best viewed in terms of its practical uses. Moreover, John Dewey thought that education is a series of reorganization and adjustment of experiences. "Learning by doing" will prepare students for their future social life. Dewey wrote in one of his books that "we learn from reflecting on experience" and his reflective knowledge theory provides ground for pluralism in learning [11]. The idea of the application of experiential learning tool coincides with Dewey's concept on education which stresses "Education as necessity of life", "Education as growth" and "Education as direction". In conclusion, while learning from life experience, students are liable to observe, explore and experience more and in doing so, they will obtain the most up-to-date and correct knowledge of energy.

With the help of the experimental apparatuses, this study was able to turn the abstract concept of renewable energy/energy conservation into a real life experience for the learners. The students were willing to take the initiative in exploring and discovering problems. In all, the energy teaching tools need to be easy to assemble, easy to popularize and above all, user friendly.

\section{MATERIALS AND METHODS}

\subsection{SUBJECTS}

Subjects of the study were divided into two groups. First group was comprised of the students from elementary/junior high schools who enrolled in the "Student experiential learning camp". The surveys were carried out year by year: 1. 2011-2012 the in-camp survey of "Perception of energy conservation and carbon reduction", 227 students; 2. 2012 in-camp survey of "Acceptance model of demonstration teaching tool", 106 students; 3. 2011-2012 in-camp survey of "Satisfaction level", 227 students. Second group consisted of the college students in the "Future energy teacher's experiential training camp". Three in-camp surveys were conducted: 1. 2011-2012 in-camp survey of "Perception of energy", 101 students; 2. 2011-2012 in-camp survey of "Behavior intention", 100 students; 3. 2012 in-camp survey of " Acceptance model of demonstration teaching tool", 56 students.

\subsection{RESEARCH FRAMEWORK}

Following the 2010 "National energy talent cultivation/integration-establishment of experiential curriculum" plan, this study has set a goal to research and develop one teaching tool every year for a designated renewable energy. 


\section{INTERNATIONAL JOURNAL Of RESEARCH -GRANTHAALAYAH

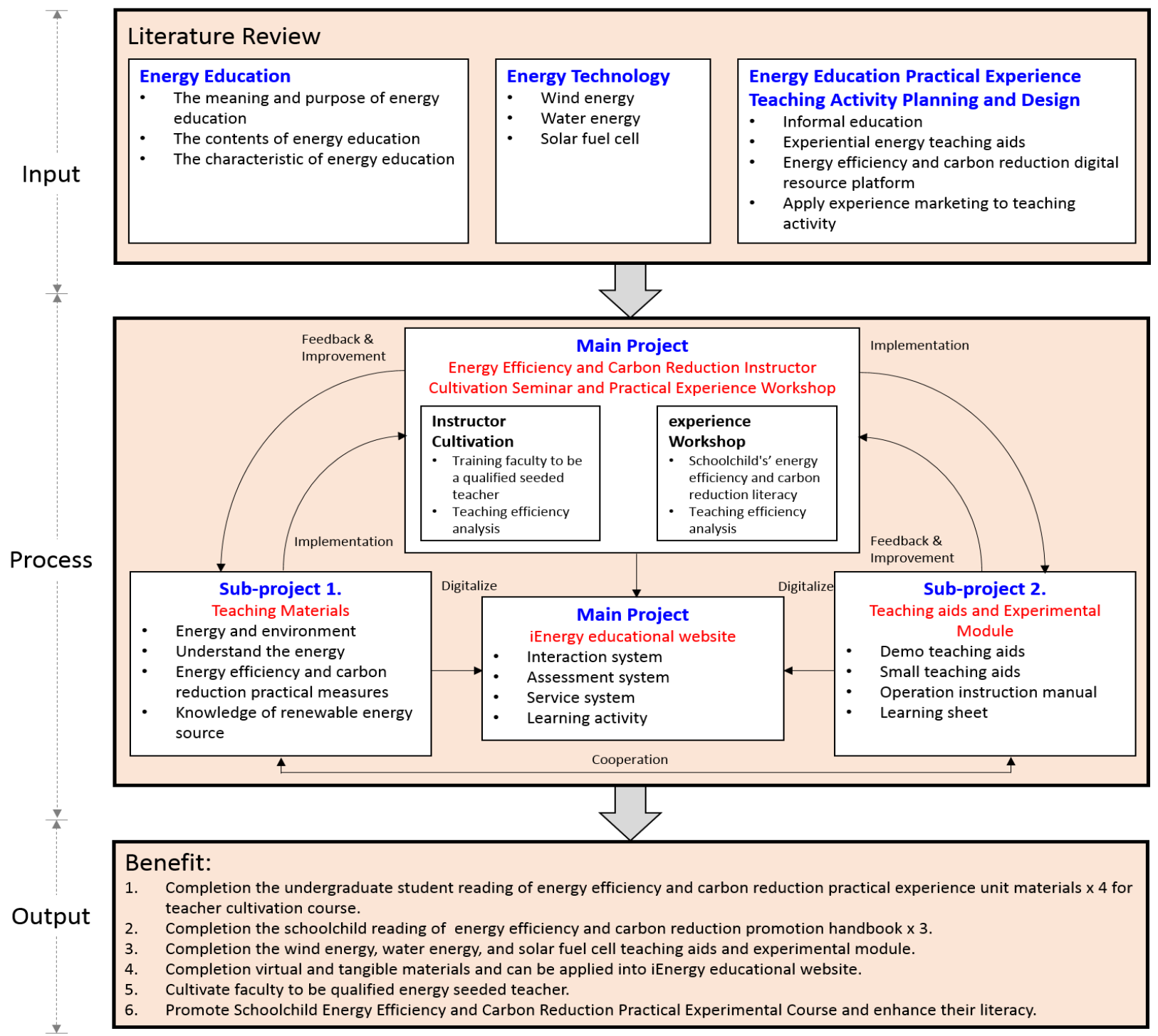

Figure 2: Research framework

\subsection{SURVEY TOOLS}

By design, this study's survey was also divided into two parts:

- Questionnaire: survey of curriculum effectiveness of "Future energy teacher's experiential training camp". This survey was further divided into three facets: 1. perception of energy saving and carbon reducing with questions in "true or false" and "multiple choice" form. 2. behavior intention of energy saving and carbon reducing: based on Theory of Planned 


\section{INTERNATIONAL JOURNAL Of RESEARCH -GRANTHAALAYAH

Behavior [12,13], the survey tried to find out how and to what extent the students' attitude, subjective norm and perceived behavioral control had affected their behavior intention of energy saving and carbon reducing. 3. demonstration teaching tool: by using Technology Acceptance Model [14,15], this survey tried to determine how and to what extent the students' "perceived ease of use", "perceived usefulness" and "attitude" had influenced their "behavior intention" to use the demonstration teaching tools. The Likert five-point scale was adopted.

Having finished the preliminary questions on perception, this study invited 105 college students to answer them online. Then we conducted the discriminated elimination, item analysis, factor analysis to obtain significant correlation between each item's CR value and total value. Finally, the Cronbach's validity test was conducted for the preparation of the formal questions. The results are as follows in Table 1.

Table 1: Questionnaire " Survey of curriculum effectiveness of Future energy teacher's experiential training camp: number of questions and internal consistency coefficient

\begin{tabular}{|c|c|c|c|c|}
\hline Questionnaire & Group & $\begin{array}{c}\text { No. of items of } \\
\text { preliminary survey }\end{array}$ & $\begin{array}{l}\text { No. of items of } \\
\text { formal survey }\end{array}$ & $\begin{array}{c}\text { Cronbach's } \\
\alpha\end{array}$ \\
\hline \multirow{2}{*}{$\begin{array}{l}\text { Behavior intention of } \\
\text { energy saving and carbon } \\
\text { reducing }\end{array}$} & Cognition & 20 & 13 & - \\
\hline & Attitude & 6 & 6 & .829 \\
\hline \multirow{4}{*}{$\begin{array}{l}\text { (TPB, theory of planned } \\
\text { behavior) }\end{array}$} & $\begin{array}{l}\text { Subjective } \\
\text { norm }\end{array}$ & 5 & 4 & .805 \\
\hline & $\begin{array}{l}\text { Perceived } \\
\text { behavioral } \\
\text { control }\end{array}$ & 6 & 5 & .770 \\
\hline & $\begin{array}{l}\text { Behavior } \\
\text { intention }\end{array}$ & 4 & 3 & .670 \\
\hline & Total & & & .881 \\
\hline $\begin{array}{l}\text { Demonstration teaching } \\
\text { tool }\end{array}$ & $\begin{array}{l}\text { Perceived } \\
\text { ease of use }\end{array}$ & 3 & 3 & .786 \\
\hline \multirow[t]{4}{*}{$\begin{array}{l}\text { (TAM, technology } \\
\text { acceptance model) }\end{array}$} & $\begin{array}{l}\text { Perceived } \\
\text { usefulness }\end{array}$ & 4 & 3 & .849 \\
\hline & Attitude & 4 & 3 & .871 \\
\hline & $\begin{array}{l}\text { Behavior } \\
\text { intention }\end{array}$ & 5 & 4 & .877 \\
\hline & Total & & & .925 \\
\hline
\end{tabular}




\section{INTERNATIONAL JOURNAL Of RESEARCH -GRANTHAALAYAH

- Questionnaire: survey of curriculum perception, satisfaction level and demonstration teaching tool : elementary and junior high school students in the "Student experiential learning camp"

The questions proposed by this study were 14 on perception; 7 on satisfaction level and 14 on demo teaching tool ( on Likert 5-point scale). This study used experts for its reliability test. The experts have scrutinized every question to make sure the wording used was suitable for the above-mentioned students.

\section{RESULTS AND DISCUSSIONS}

(1) Maneuverable teaching tool/experimental module for the renewable energy education

This research has developed several compact teaching tool sets (Table 2), including a windmill generator, a hydro generator, a dye-sensitized solar cell and a solar powered boat, etc. Students were given the opportunity to assemble them and to experiment them for themselves for the purpose of gaining experience through "learning by doing". By switching to different materials/configurations, students were also able to weigh the factors affecting the electricity output for the purpose of maximizing the generation efficiency.

This study has also come up with three large demonstration teaching tools (Table3), namely a set of hydro generator, a set of solar power fuel cell and a composite teaching tool monitoring module. Among them, the hydro generator has taken out a prototype patent (patent number M441900) while the solar power fuel cell's patent is still pending.

Table 2: Compact teaching tool set: type, content of experiment, content of worksheet

\begin{tabular}{|c|c|c|}
\hline $\begin{array}{c}\text { Type of } \\
\text { teaching tool }\end{array}$ & Content of experiment & Content of worksheet \\
\hline $\begin{array}{l}\text { Windmill } \\
\text { generator } \\
\text { teaching tool } \\
\text { module }\end{array}$ & $\begin{array}{l}\text { 1.Swept area (size) } \\
\text { 2. No. of rotor blade }(2,3,4,5,6) \text {, } \\
\text { 3. Material of rotor blade (paper, soft } \\
\text { plastic, hard plastic) } \\
\text { 4. Angle of attack ( } 30,45,60 \text { degrees) } \\
\text { 5. Shape of rotor blade (airfoil, flat, } \\
\text { cone, cylinder) }\end{array}$ & $\begin{array}{l}\text { 1. To observe variations caused by changing } \\
\text { experimental variables, to record observed } \\
\text { data and relevant factors through group } \\
\text { discussion. }\end{array}$ \\
\hline $\begin{array}{l}\text { Hydro } \\
\text { generator } \\
\text { teaching tool } \\
\text { module }\end{array}$ & $\begin{array}{l}\text { 1. Head (High/Low Drop) } \\
\text { 2. Flow (High/Low Volume } \\
\text { 3. Speed (High/Low) }\end{array}$ & $\begin{array}{l}\text { 1. To observe variations caused by changing } \\
\text { experimental variables, to record observed } \\
\text { data and relevant factors through group } \\
\text { discussion. }\end{array}$ \\
\hline
\end{tabular}




\section{INTERNATIONAL JOURNAL Of RESEARCH -GRANTHAALAYAH

4. Size of Pipe (Large/Small Diameter)

5. Position of Attack On Blade

(Tip/Inner)

\section{Area of Attack on Blade \\ (Large/Small)}

Solar powered This small DIY solar powered boat is boat composed of a mini propeller and some solar panels. The learning objective is to maximize the power output of these solar panels.
2. To be able to design a hydro generator with engineering design theory and blueprint
To make a draft of the boat first; to take the finished prototype boat for a voyage in the water bucket; to study the power output changes in relation to the change of angle between sun rays and solar panels.

Table 3: Demonstration teaching tool: type, contents of experiment and description

\begin{tabular}{|c|c|c|}
\hline Type & Content of Experiment & Description \\
\hline $\begin{array}{l}\text { Hydro generator } \\
\text { demo teaching } \\
\text { tool }\end{array}$ & $\begin{array}{l}\text { 1. Change of head } \\
\text { 2. Change of flow } \\
\text { 3. Change of attack angle }\end{array}$ & $\begin{array}{l}\text { With different experimental variables, to observe and } \\
\text { compare the change in voltage, current and brightness of } \\
\text { LED light bulb. to discuss and record how the change } \\
\text { of setting affects the electricity output }\end{array}$ \\
\hline $\begin{array}{l}\text { Solar power fuel } \\
\text { cell demo } \\
\text { teaching tool }\end{array}$ & $\begin{array}{l}\text { 1. Source of light: } \\
\text { bright/dim (simulating sun } \\
\text { rays) } \\
\text { 2. Angle between light } \\
\text { and solar panels } \\
\text { (simulating sun rays at } \\
\text { different times) } \\
\text { 3. Solution in fuel cell } \\
\text { (adding acid or alkali) } \\
\text { 4. Measurement of load }\end{array}$ & $\begin{array}{l}\text { Observation, experiment comparing various generation } \\
\text { variables affect the solar panel, thereby affecting the } \\
\text { load capacity and the brightness of the LED on the } \\
\text { impact of various conditions on the amount of power, } \\
\text { and recorded. }\end{array}$ \\
\hline $\begin{array}{l}\text { Composite } \\
\text { teaching tool } \\
\text { monitoring } \\
\text { module }\end{array}$ & $\begin{array}{l}\text { 1. Windmill generator } \\
\text { 2. Hydro generator } \\
\text { 3. Solar power fuel cell }\end{array}$ & $\begin{array}{l}\text { To use a single power source from renewable energy as } \\
\text { power supply to observe its efficiency and the voltage, } \\
\text { current at the load end; also to observe the supply } \\
\text { interactive mode when multiple power sources are } \\
\text { applied }\end{array}$ \\
\hline
\end{tabular}

(2) iEnergy educational website for energy saving and carbon reducing 


\section{INTERNATIONAL JOURNAL Of RESEARCH -GRANTHAALAYAH

The internet address of this educational site is http//phsu.ie.ntnu.edu.tw/ienergy/. This site features teaching materials in both virtual and real fashion. It has attracted 296,947 web viewers up to April 27, 2013. This educational website for energy saving and carbon reducing centers around the introduction of basic principles and the objective depiction of the step-by-step usage. Plain language along with straightforward illustrations/animations constitutes its main frame. Also the easy access to the vivid and interactive multimedia enables it to be a source of combined teaching materials, both virtual and real to supplement the deficiency of the traditional teaching materials.

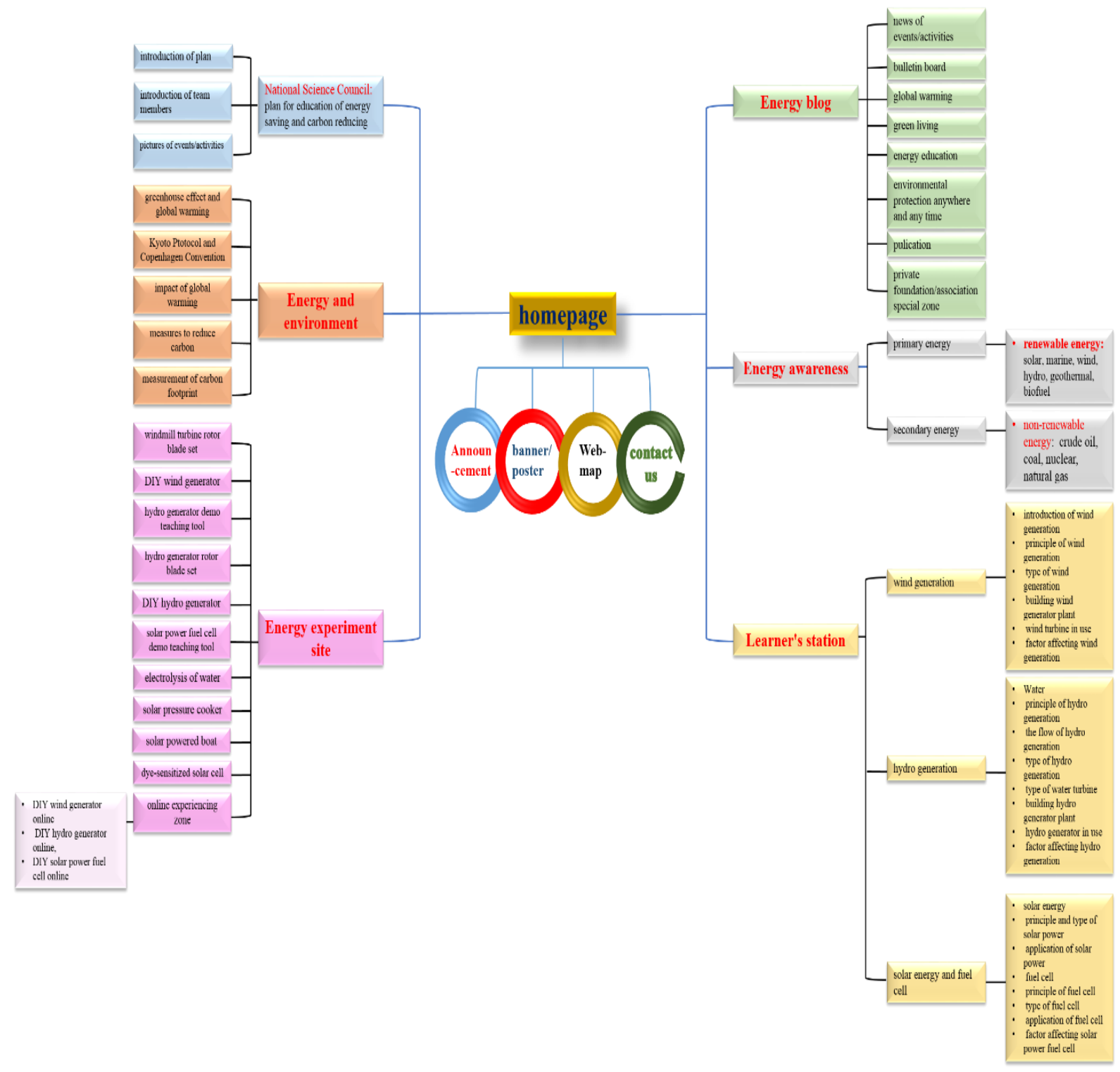

Figure 3: Educational website for energy saving and carbon reducing: framework and content 


\section{INTERNATIONAL JOURNAL Of RESEARCH -GRANTHAALAYAH \\ A knowledge Repository}

Science

Table 4: Planned activities of interactive digital teaching materials

\begin{tabular}{|c|c|c|}
\hline Item & Step & Learning content \\
\hline \multirow[t]{4}{*}{$\begin{array}{l}\text { Online } \\
\text { DIY wind } \\
\text { generator }\end{array}$} & Winding of coil & $\begin{array}{l}\text { Calculate the number of coil winding in } 30 \text { seconds; learn more } \\
\text { coil winding number, the higher the efficiency of power } \\
\text { generation. }\end{array}$ \\
\hline & Installing generator & $\begin{array}{l}\text { Understand the relative position of motor and wind generator; to } \\
\text { increase interest of learning through interaction. }\end{array}$ \\
\hline & $\begin{array}{l}\text { Installing rotor blade } \\
\text { set }\end{array}$ & $\begin{array}{l}\text { Adjust the blade area, the number of blade, the blade material } \\
\text { along with controlled variable wind speed; to observe and } \\
\text { measure the outcome by manipulating the combination of } \\
\text { variables. }\end{array}$ \\
\hline & Pop quiz & $\begin{array}{l}\text { Three questions are given and followed by answers for immediate } \\
\text { feedback. }\end{array}$ \\
\hline \multirow{6}{*}{$\begin{array}{l}\text { Online } \\
\text { DIY hydro } \\
\text { generator }\end{array}$} & Selecting blade size & $\begin{array}{l}\text { Other things being equal, the size of the area where water hits the } \\
\text { blades will affect the speed of the rotor. }\end{array}$ \\
\hline & $\begin{array}{l}\text { Installing blade set } \\
\text { to power house }\end{array}$ & $\begin{array}{l}\text { Understand the relative position of the water turbine; to increase } \\
\text { interest of learning through interaction. }\end{array}$ \\
\hline & Changing the head & The long vertical distance of high head will generate more power. \\
\hline & Changing the flow & $\begin{array}{l}\text { The flow is directly proportioned to the size of pipe and speed; } \\
\text { proper flow and proper speed is essential to steady generation. }\end{array}$ \\
\hline & $\begin{array}{l}\text { Changing the water } \\
\text { attack position on } \\
\text { blades }\end{array}$ & $\begin{array}{l}\text { If water hits the tip of the blades, the velocity of spinning will } \\
\text { result in more power generation; on the contrary, if the struck } \\
\text { position is on the inner section of the blades, the electricity } \\
\text { generated will be less. }\end{array}$ \\
\hline & Q \& A challenge & $\begin{array}{l}\text { Seven questions will be asked of students and correct answers } \\
\text { will be provided for immediate feedback. }\end{array}$ \\
\hline \multirow{3}{*}{$\begin{array}{c}\text { Online } \\
\text { DIY solar } \\
\text { power fuel } \\
\text { cell }\end{array}$} & $\begin{array}{l}\text { Selecting the } \\
\text { components }\end{array}$ & $\begin{array}{l}\text { Use a mouse to select proper components to create the solar } \\
\text { energy fuel cell. }\end{array}$ \\
\hline & $\begin{array}{l}\text { Assembling the } \\
\text { components }\end{array}$ & $\begin{array}{l}\text { Use a mouse to place the components in proper place to create the } \\
\text { workable solar energy fuel cell. }\end{array}$ \\
\hline & Animating the & View the animation of how solar power fuel cell works, to view \\
\hline
\end{tabular}




\section{INTERNATIONAL JOURNAL Of RESEARCH -GRANTHAALAYAH \\ A knowledge Repository}

Science

operation

Changing the brightness of sun rays Changing the angle of sun rays

Changing the water electrolyte

Q \& A challenge the demonstration and explanation of the electrolysis of water on the left side.

Adjust the bright/dim setting and observe the brightness change of the light bulb with that of the sun rays.

Adjust the angle setting and observe the brightness change of the light bulb as sun rays move to different angle.

Click on "type of electrolyte" to choose pure water, strong acid, and strong alkaline; to observe the color change of water and the brightness change of the light bulb.

Ten questions are given to the students followed by correct answers for immediate feedback.

(3) "Future energy teacher's experiential training camp", "Student experiential learning camp" and other promotional events/activities

This study has sponsored promotional activities by holding a "Future energy teacher's experiential training camp" for college students and a "Student experiential learning camp" for students from fourth grade of elementary schools to second year of junior high schools. The study has also helped with other promotional events/activities as a co-sponsor. From 2011 to 2012, the "Future energy teacher's experiential training camp" was held five times with six times for the "Student experiential learning camp". The study also co-sponsored 13 events/promotional activities during that period.

\section{(4) Statistical analysis of questionnaire}

To better understand the curriculum effectiveness of the energy education, the study has drawn up the questionnaire "Survey of curriculum effectiveness of the "Future energy teacher's experiential training camp" to survey the participating college students in the area of their perception change, behavior intention of energy saving and carbon reducing and their opinions on the demo teaching tools. As for the participating students from the elementary and junior high schools, our self-designed questionnaires "Survey of curriculum perception, satisfaction level and demo teaching tool in the "Student experiential learning camp" were conducted with extra space in the questionnaires for open-ended comment/suggestion. The feedback will serve as a reference for future curricular and teaching improvement.

A. Analysis of learning effectiveness of college student participants in the "Future energy teacher's experiential training camp" 


\section{INTERNATIONAL JOURNAL Of RESEARCH -GRANTHAALAYAH

A survey was conducted by giving the college students a pretest and a posttest. Then the grades went through the dependant sample $t$ test to ascertain the grade differences in their energy knowledge before and after joining the camp. The results reflect that the differences are statistically significant as shown in Table 5 .

Table 5: Summary of $t$ test analysis: participants in the "Future energy teacher's experiential training camp"

\begin{tabular}{cccccc}
\hline Year & & $\mathrm{N}$ & Mean & SD & t value \\
\hline 2011 & Pretest & 48 & 9.27 & 1.90 & $-8.56^{* * * *}$ \\
& Posttest & 48 & 11.47 & 1.37 & \\
2012 & Pretest & 53 & 10.43 & 1.91 & $-6.01 * * *$ \\
& Posttest & 53 & 11.85 & 1.08 & \\
\hline$* * * \mathrm{p}<.001$ & & & & &
\end{tabular}

B. Analysis of behavior intention to save energy and reduce carbon for participants in the "Future energy teacher's experiential training camp"

The correlation coefficients of the four variables are illustrated in Table 6 (for year 2011) and Table 7 (for year 2012), respectively. The results reveal that the subjects' "attitude toward behavior", "subjective norm" and "perceived behavioral control" are influential in their "behavior intention" and hence they should not be ignored.

Table 6: Summary of the correlation coefficient of the variables, average, standard deviation and no. of respondents (2011 "Future energy teacher's experiential training camp).

\begin{tabular}{ccccc}
\hline Domains & $\begin{array}{c}\text { Attitude toward } \\
\text { behavior }\end{array}$ & subjective norm & $\begin{array}{c}\text { Perceived behavioral } \\
\text { control }\end{array}$ & $\begin{array}{c}\text { Behavior } \\
\text { intention }\end{array}$ \\
\hline Attitude toward behavior & 1 & & & \\
Subjective norm & $.356^{*}$ & 1 & & \\
Perceived behavioral control & $.393^{* *}$ & $.343^{*}$ & 1 & \\
Behavior intention & $.569^{* * *}$ & $.431^{* *}$ & $.437^{* *}$ & 1 \\
Average & 27.53 & 15.94 & 21.65 & 12.80 \\
\hline
\end{tabular}




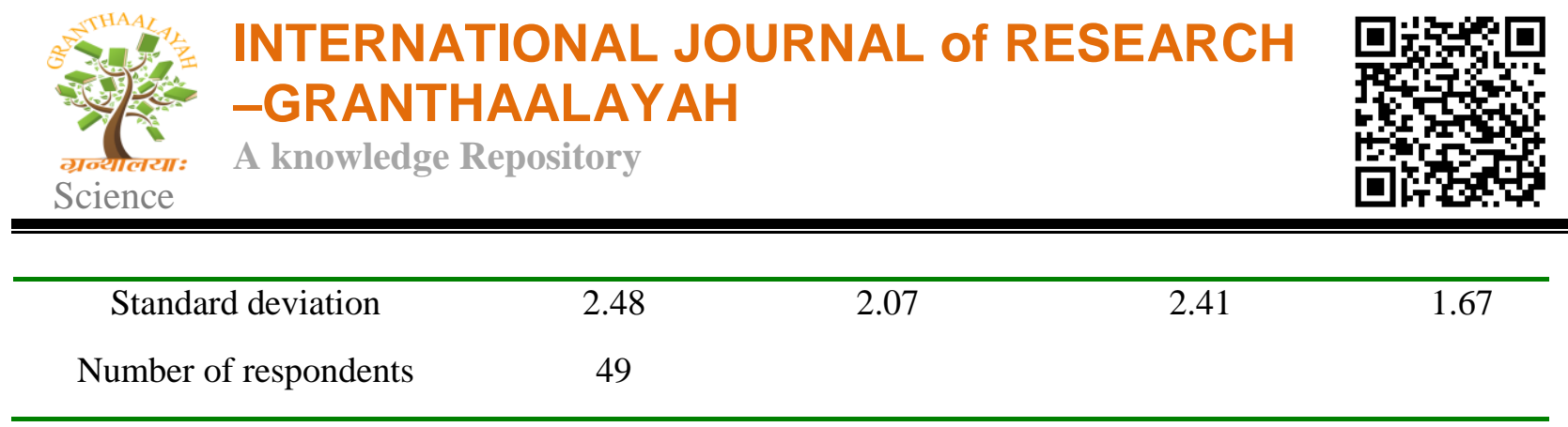

$* \mathrm{p}<.05, * * \mathrm{p}<.01, * * * \mathrm{p}<.001$

Table 7: Summary of the correlation coefficient of the variables, average, standard deviation and no. of respondents (2012 "Future energy teacher's experiential training camp)

\begin{tabular}{lcccc}
\hline \multicolumn{1}{c}{ Domains } & $\begin{array}{c}\text { Attitude toward } \\
\text { behavior }\end{array}$ & subjective norm & $\begin{array}{c}\text { Perceived behavioral } \\
\text { control }\end{array}$ & $\begin{array}{c}\text { Behavior } \\
\text { intention }\end{array}$ \\
\hline Attitude toward behavior & 1 & 1 & & \\
Subjective norm & $.554^{* * *}$ & $.446^{* *}$ & 1 & \\
Perceived behavioral control & $.583^{* * *}$ & $.648^{* * *}$ & $.489^{* * *}$ & 1 \\
Behavior intention & $.593^{* * *}$ & 12.82 & 27.96 & 21.47 \\
Average & 14.04 & 1.62 & 2.65 & 3.26 \\
Standard deviation & 1.23 & & & \\
Number of respondents & 51 & & & \\
\hline
\end{tabular}

$* \mathrm{p}<.05, * * \mathrm{p}<.01, * * * \mathrm{p}<.001$

C. Demo teaching tool Acceptance Model analysis for participants in the "Future energy teacher's experiential training camp"

This survey on the demo teaching tool was added in 2012. First, the one-sample t test was conducted on the data collected (test value preset at 4). Table 8 demonstrates a satisfaction level on the demo teaching tool in terms of its perceived ease of use, perceived usefulness, attitude toward behavior and behavior intention. From the correlation coefficient analysis of Table 9, it could be ascertained that all four variables are interrelated, with attitude toward behavior having the highest correlation coefficient with behavior intention. Therefore, in the future, if we are to increase the possibility and frequency of the use of demo teaching tool, we need to first work on students' positive attitude toward them. 


\section{INTERNATIONAL JOURNAL Of RESEARCH -GRANTHAALAYAH \\ A knowledge Repository}

Science

Table 8: Summary of t test of demo teaching tool (solar power fuel cell) for participants in the "Future energy teacher's experiential training camp"

\begin{tabular}{ccccc}
\hline Domains & N & Mean & SD & t value \\
\hline Perceived ease of use & 56 & 4.16 & .56 & $2.14^{*}$ \\
Perceived usefulness & 56 & 4.48 & .49 & $7.31^{* * *}$ \\
Attitude toward behavior & 56 & 4.52 & .51 & $7.71^{* * *}$ \\
Behavior intention & 56 & 4.58 & .46 & $9.43^{* * *}$ \\
\hline
\end{tabular}

$* \mathrm{p}<.05, * * \mathrm{p}<.01, * * * \mathrm{p}<.001$

Table 9: Summary of the correlation coefficient of the variables: demo teaching tool (solar power fuel cell) for the participants in the "Future energy teacher's experiential training camp"

\begin{tabular}{lcccc}
\hline \multicolumn{1}{c}{ Domains } & $\begin{array}{l}\text { Perceived ease } \\
\text { of use }\end{array}$ & $\begin{array}{l}\text { Perceived } \\
\text { usefulness }\end{array}$ & Attitude toward behavior & $\begin{array}{c}\text { Behavior } \\
\text { intention }\end{array}$ \\
\hline Perceived ease of use & 1 & & & \\
Perceived usefulness & $.577^{* * *}$ & 1 & 1 & 1 \\
Attitude toward behavior & $.578^{* * *}$ & $.704^{* * *}$ & $.748 * * *$ & 4.58 \\
Behavior intention & $.646^{* * *}$ & $.594 * * *$ & 4.52 & .46 \\
Average & 4.16 & 4.48 & .51 & \\
Standard deviation & .56 & .49 & & \\
Number of respondents & 56 & & &
\end{tabular}

D. Analysis of the learning effectiveness of elementary/junior high school participants in the "Student experiential learning camp"

A dependant sample t test was conducted on the grades of pretest and posttest which were given to the students to find out if there was any improvement of grades in their perception/knowledge of energy saving and carbon reducing after joining the camp. As shown in Table 10, the results indicate a significant improvement for students who have joined the camp. 


\section{INTERNATIONAL JOURNAL Of RESEARCH -GRANTHAALAYAH \\ A knowledge Repository}

Science

Table 10: Summary of $\mathrm{t}$ test analysis: participants in the "Student experiential learning camp"

\begin{tabular}{cccccc}
\hline Year & & $\mathrm{N}$ & Mean & SD & t value \\
\hline 2011 & Pretest & 117 & 10.35 & 1.86 & $-5.427^{* * *}$ \\
& Posttest & 117 & 11.32 & 1.95 & \\
2012 & Pretest & 110 & 10.40 & 1.68 & $-7.06^{* * * *}$ \\
& Posttest & 110 & 11.62 & 1.50 & \\
\hline$* * * \mathrm{p}<.001$ & & & & &
\end{tabular}

E. Demo teaching tool Acceptance Model analysis: participants in the "Student experiential learning camp"

First, based on the data collected, the single sample t test (test value preset at 4) was conducted. The averages shown in Table 11 indicate a satisfactory level for perceived usefulness, attitude toward behavior and behavior intention with the exception of perceived ease of use. In conclusion, the demo teaching tools designed by this study may just be a little too difficult for the elementary/junior high school students to master. Future improvement, if any, may focus on the designing of simpler operational procedures. Further, the correlation coefficient of variables shown in Table 12 suggests a correlation among the four variables. Like the survey results of the "Future energy teacher's experiential training camp", the attitude toward behavior has the highest correlation coefficient with the behavior intention. Thus, in the future, the adoption of demo teaching tools and their use frequency may largely depend on the cultivation of students' positive attitude toward them.

Table 11: Summary of $t$ test of demo teaching tool (solar power fuel cell) for participants in the "Student experiential learning camp"

\begin{tabular}{ccccc}
\hline Domains & $\mathrm{N}$ & Mean & SD & t value \\
\hline Perceived ease of use & 106 & 4.12 & .81 & 1.56 n.s. \\
Perceived usefulness & 106 & 4.32 & .87 & $3.78^{* * * *}$ \\
Attitude toward behavior & 106 & 4.33 & .78 & $4.38^{* * *}$ \\
Behavior intention & 106 & 4.25 & .80 & $3.28^{* *}$ \\
\hline
\end{tabular}

n.s. $\mathrm{p}>.05, * * \mathrm{p}<.01, * * * \mathrm{p}<.001$ 


\section{INTERNATIONAL JOURNAL Of RESEARCH -GRANTHAALAYAH

Table 12: Summary of the correlation coefficient of the variables: demo teaching tool (solar power fuel cell) for participants in the "Student experiential learning camp"

\begin{tabular}{|c|c|c|c|c|}
\hline Domains & $\begin{array}{l}\text { Perceived } \\
\text { ease of use }\end{array}$ & Perceived usefulness & Attitude toward behavior & $\begin{array}{l}\text { Behavior } \\
\text { intention }\end{array}$ \\
\hline Perceived ease of use & 1 & & & \\
\hline Perceived usefulness & $.706^{* * *}$ & 1 & & \\
\hline Attitude toward behavior & $.738 * * *$ & $821 * * *$ & 1 & \\
\hline Behavior intention & $.732 * * *$ & $.847 * * *$ & $.898 * * *$ & 1 \\
\hline Average & 4.12 & 4.32 & 4.33 & 4.25 \\
\hline Standard deviation & .81 & .87 & .78 & .80 \\
\hline Number of respondents & 106 & & & \\
\hline \multicolumn{5}{|l|}{$* * * \mathrm{p}<.001$} \\
\hline \multicolumn{5}{|c|}{ F. Survey of satisfaction level of participants in the "Student experiential learning camp" } \\
\hline \multicolumn{5}{|c|}{$\begin{array}{l}\text { Participation in the "Student experiential learning camp" has helped the students to better } \\
\text { understand the energy-related issues to the extent that the differences are statistically significant } \\
\text { as demonstrated in Table } 13 \text {. }\end{array}$} \\
\hline \multicolumn{5}{|c|}{ Table 13: Summary of $t$ test of participants in the "Student experiential learning camp" (no. 1) } \\
\hline Questiol & & Year & Mean & t value \\
\hline \multirow{2}{*}{\multicolumn{2}{|c|}{$\begin{array}{l}\text { Participate in this camp can help you } \\
\text { understand the energy-related issues? }\end{array}$}} & $2011 \quad 117$ & 2.76 & $-5.012 * * *$ \\
\hline & & $2012 \quad 109$ & 2.78 & $6.11^{* * *}$ \\
\hline
\end{tabular}

The level of satisfaction of participants in the "Student experiential learning camp" is shown in Table 14, showing the differences are significant. Particularly, during the survey process, students have shown a strong interest in the experiment of the wind generator and the hydro generator. 


\section{INTERNATIONAL JOURNAL Of RESEARCH -GRANTHAALAYAH

Table 14: Summary of t test of participants in the "Student experiential learning camp" (no. 2)

\begin{tabular}{lccccc}
\hline \multicolumn{1}{c}{ Question } & Year & $\mathrm{N}$ & Mean & $\mathrm{SD}$ & $\mathrm{t}$ value \\
\hline $\begin{array}{l}\text { Are you satisfied with the curriculums } \\
\text { arranged by this camp? }\end{array}$ & 2011 & 117 & 2.65 & .56 & $-6.745^{* * *}$ \\
& 2012 & 109 & 2.70 & .50 & $4.12^{* * *}$ \\
\hline$* * * \mathrm{p}<.001$ & & & & &
\end{tabular}

The study has completed curriculums with courses offering learning from both knowledge and experience with the assistance of multimedia digital experiential learning materials. These curriculums and materials are helpful in designing the adequate courses for the ultimate goal of sustainable development. Based on the review of the related literature, this study has created experiential courses of energy education in the following aspects: (1) knowledge and awareness: getting to know energy, energy and environment, renewable energy technology. (2) Affection: specific way to conserve energy and reduce carbon. (3) skills/know ( how: compact teaching tools including a DIY wind generator, a DIY water generator, a dye-sensitized solar cell, a solar powered boat and a mini solar pressure cooker; large demo teaching tools including a hydro generator demo unit, a solar power fuel cell demo unit and a composite teaching tool monitoring module. Conclusively, this study has integrated learning from knowledge and learning from experience with the introduction of multimedia teaching materials in both real and virtual fashion.

The setup of the educational website for energy-saving and carbon reducing by this study plays an important role in providing substantial enrichment to the educational resources of sustainable development. As a result, students will benefit a lot in their knowledge of energy. By participating in the "Future energy teacher's experiential training camp", the college students have acquired sufficient knowledge of energy. The learning effectiveness examination of the participants in the "Future energy teacher's experiential training camp" has shown a significant improvement on their grades after joining the camp. That indeed is an indication that the students have enhanced their awareness and knowledge of energy saving and carbon reducing through the camp activities and website resources. Having accomplished the goal of training future teachers, the researchers of this study are hoping that these prospective energy teachers, with the proficient knowledge/experience gained at the camp, can spread what they have learned to their college campuses and future work places.

The curricular activities of the "Student experiential learning camp" have proved to be helpful in the enhancement of the awareness and knowledge of the participating elementary/junior high school students. The survey results have confirmed the fact that the differences in learning effectiveness are significant for the students taking part in the "Student experiential learning camp". This is to say that the camp curriculums and the educational website do play an important role in the improvement of their knowledge of energy. The questionnaires conducted 


\section{INTERNATIONAL JOURNAL of RESEARCH -GRANTHAALAYAH

also serve as an indication that these students are now more than willing to help promote the ideas of energy saving and carbon reducing at school and at home. These educated students are now willing to reach out and touch someone to make a difference with their correct knowledge of energy.

The "learning by doing" curriculums have strengthened the students' behavior intention to conserve energy and reduce carbon which is instrumental in the promotion of energy topics of the sustainable development education. The attitude toward behavior, subjective norm and perceived behavioral control of the college students will no doubt pave the way for their behavior intention to save energy and reduce carbon. Therefore, the planning of energy curriculums in the future may need to lay more weight on the "affection" element. The tuning of the curriculums will definitely benefit the cultivation of future teachers. The perceived ease of use, perceived usefulness and attitude of the elementary/junior high school students toward the demo teaching tools directly affect their intention to use them. These students are most satisfied with the curriculums of the "Student experiential learning camp", especially with the experiential courses with both dynamic and static elements. These courses will not only enhance the students' knowledge of energy, but also arouse their interest in the energy technology. It is also discovered in the survey that the students generally show a higher interest in the experiential courses. So for the camp activities to follow, the experiential education should be the mainstream of them with didactic learning being the supplement.

\section{CONCLUSIONS \& RECOMMENDATIONS}

This study considers the informal education as a vital means of helping college students and students from elementary/junior high schools to gain better knowledge of energy conservation and carbon reduction. Pertinent experiential teaching materials, maneuverable teaching tools/experimental modules and an educational website were created and utilized in both the "Future energy teacher's experiential training camp" and the "Student experiential learning camp"

Education for sustainable development provides a platform of education including the contents, means and the implementation of it for the ultimate sustainability of the human world. The power of education helps the general public with their belief, ability and attitude in the context of sustainable development. With respect to the innovation and pluralism of education for sustainable development, the energy education should be something different from the traditional one. It is therefore suggested that, in order to deal with the difficulties faced by the energy education in the elementary schools, the experiential learning, DIY courses, educational website and other types of blended learning should be adopted as the backbone of the curriculums. As for the educators of sustainable development, active teachers are required to take formal on-thejob training on energy issues. Further, the informal education models are also suggested in an 


\section{INTERNATIONAL JOURNAL Of RESEARCH -GRANTHAALAYAH \\ A knowledge Repository}

Science

effort to foster college students to become seed instructors. In the meantime, the academic subject of "energy conservation and carbon reduction" could be considered as a college mandatory course or offered as an elective. This is for the enhancement of college students' knowledge in that field and also for the strengthening of their behavior intention to get involved. In short, teacher cultivation is the key to successfully promoting the ideals of education for sustainable development.

\section{ACKNOWLEDGEMENTS}

This research project would not have been possible without the subsidies from the Nation Science Council: Project no.: NSC 100-3113-S-003-011 and NSC 101-3113-S-003-010. We'd like to express our deepest gratitude to them.

\section{REFERENCES}

[1] UNESCO. United Nations Decade of Education for Sustainable Development. Retrieved June 13, 2014, from

http://portal.unesco.org/education/admin/ev.php?URL_ID=23295\&URL_DO=DO_TOPIC \&URL_SECTION=201; 2002.

[2] UNFCCC. United Nations Framework Convention on Climate Change. Retrieved June 13, 2014, from http://unfccc.int/2860.php; 2009.

[3] IPCC. Climate Change 2007: The Physical Science Basis. Contribution of Working Group I to the Fourth Assessment Report of the Intergovernmental Panel on Climate Change.

Cambridge: Cambridge University Press; 2007.

[4] Wu, C.-S., Wang, L.-Y. and Huang, C.-H. A Study of Education for Sustainable Development in Elementary Schools. Curriculum \& Instruction Quarterly. Vol. 17, No. 2, 2014, 93-118.

[5] Greenberg, M. T., Weissberg, R. P.; O'Brien, M. U., Zins, J. E.; Fredericks, L.; Resnik, H., Elias, M. J. Enhancing school-based prevention and youth development through coordinated social, emotional, and academic learning. American Psychologist, Vol. 58, 2003, 466-474.

[6] Tyler, R. W. Basic Principles of Curriculum and Instruction. Chicago: The Univ. of Chicago; 1949.

[7] Dewey, J. Experience and Education. London: Collier Macmillan; 1938, 28.

[8] Olive,r A. I. Curriculum Improvement (2nd ed.). NY: Harper \& Row; 1977. 


\section{INTERNATIONAL JOURNAL Of RESEARCH -GRANTHAALAYAH

[9] Fenichel, M., Schweingruber, H. Surrounded by science: Learning science in informal environments: National Academy Press; 2010.

[10] Vadeboncoeur, J. A., Collie, R. J. Locating Social and Emotional Learning in Schooled Environments: A Vygotsky Perspective on Learning as Unified. Mind, Culture, and Activity, Vol. 20, 2013, 201-225.

[11] Ye, Y.-H., Hsieh F.-H. An Inquiry into Ontology of Educational Research through J. Dewey's "Reflection". NTTU Educational Research Journal. Vol. 22, No. 1, 2011, 1-24.

[12] Ajzen, I. From intentions to actions: A theory of planned behavior. In J. Kuhl \& J. Beckman (Eds.), Action-control: From cognition to behavior, 11- 39. Heidelberg, Germany: Springer; 1985.

[13] Ajzen, I. The theory of planned behavior. Organizational Behavior and Human Decision Processes, Vol. 50, No. 2, 1991, 179-211.

[14]Davis F. D. A technology acceptance model for empirically testing new end-user information systems: theory and results, Ph.D. dissertation, MIT Sloan School of management, Cambridge, MA; 1986.

[15]Davis, F. D. Perceived usefulness, perceived ease of use, and user acceptance of information technology. MIS Quarterly, Vol. 13, No. 3, 1989, 319-340. 